\title{
Hunting Behaviour of a Swainson's Hawk
}

by Bill Richards, Saskatoon

Almost everyone on the prairies has observed the familiar sight of gulls following the farmer's implements waiting for tidbits of food to be uncovered. This summer I observed another way in which man's activities have been used to advantage in providing food for a Swainson's Hawk.

During the month of July, 1961, I was working on a railway mowing machine. Our job was to mow the weeds, grass and brush along the track, cutting a swath about ten feet wide on each side. As we clattered along, we flushed a steady stream of nesting birds, partridges, rabbits, and mice which scurried away out of danger as we passed by.

While working our way eastward through the Bad Hills near Greenan, Saskatchewan (about 25 miles east of
Eston), I became aware of a shadow of a large bird which was criss-crossing the railway right-of-way. I glanced up and saw a Swainson's Hawk following us quite closely. His patrolling paid off, for a short time later he swooped down and nabbed a mouse by the fence.

Evidently the hawk realized that here was an opportunity to cash in on some fairly easy pickings. The noise of our machines provided the "brush-beating" necessary in flushing the mouse while the hawk waited for the opportune moment to strike. I considered it smart behaviour on the part of the hawk as I watched it fly away with its prize. Sometimes farmers tell of seeing hawks circling over them as they cultivate a field, watching in a similar way for rodents flushed from cover.

\section{An Outbreak of Botulism in the Regina Waterfowl Park}

\author{
by Rick Sanderson, Regina
}

Returning to the Regina Waterfowl Park on September 4, 1961, after a month's absence, I noticed many dead and crippled waterfowl and shorebirds. Mr. Elmer Fox, and later the Department of Natural Resources, suggested this was botulism.

A report of a similar outbreak which occurred at Old Wives' Lake is contained in the July, 1960, issue of the Blue Jay.

I estimated that at least 300 birds were affected. Of the 264 birds of 18 species that were found with the disease, 100 were Green-winged Teal, 43 Soras, 38 Mallards, 34 Bluewinged Teal, and 25 Lesser Yellowlegs. Other species represented, but in no substantial numbers, were: Pied-billed Grebe, Gadwall, Pintail, American Widgeon (which was found to have been banded one month earlier in northern Saskatchewan), Shoveler, Ruddy Duck, Coot, Greater Yellowlegs, Pectoral Sandpiper, Least Sandpiper, Ring-billed Gull (one immature), Yellow-headed Blackbird.

The area of the Waterfowl Park that appeared to be the hardest hit was the shore of what is called "Goose Island," directly south of the city power house. Nearly all of the diseased birds were found here where waterfowl and waders congregate because there is a lot of open shore and where the water is rather stagnant in late summer. Of those species of ducks that frequent deeper water, no dead were found.

The number of dead Soras (43) found within such a confined area is striking. Of these 40 were found among the reeds on the north shore of Goose Island, all in an upright position.

Green-winged Teal evidently suffered the greatest loss in number, with a total of 100 affected birds being found. There were a large number of this species in the Park at the time.

This is apparently the first time such an outbreak has occurred in the Waterfowl Park. Botulism is an uncommon disease, occurring in extremely dry, hot years when duck populations are already drastically reduced by poor nesting conditions. 